\title{
Systematic review of multi-symptom conditions in Gulf War veterans
}

\author{
HOLLIE V. THOMAS ${ }^{1}$, NICOLA J. STIMPSON ${ }^{1}$, ALISON L. WEIGHTMAN ${ }^{2}$, \\ FRANK DUNSTAN ${ }^{3}$ AND GLYN LEWIS ${ }^{4 *}$ \\ ${ }^{1}$ Department of Psychological Medicine, School of Medicine, Cardiff University, UK; ${ }^{2}$ Department of \\ Information Services, School of Medicine, Cardiff University, UK, ${ }^{3}$ Department of Epidemiology, \\ Statistics and Public Health, School of Medicine, Cardiff University, UK, ${ }^{4}$ Academic Unit of Psychiatry, \\ University of Bristol, $U K$
}

\begin{abstract}
Background. Gulf War veterans have a number of health complaints. We therefore decided to carry out a systematic review to identify and summarize the findings from studies that have assessed multi-symptom conditions in Gulf War veterans and in an unexposed comparison group.

Method. Studies published between January 1990 and May 2004 were identified by searching a large number of electronic databases. Reference lists and websites were also searched and key researchers were contacted. Studies were included if they compared the prevalence of chronic fatigue syndrome, multiple chemical sensitivity, CDC-defined chronic multi-symptom illness, fibromyalgia, or symptoms of either fatigue or numbness and tingling in Gulf War veterans and non-Gulf veterans. A total of 2401 abstracts were independently reviewed by two authors.
\end{abstract}

Results. Twenty-three publications fulfilled the inclusion criteria. Gulf deployment was most strongly associated with chronic fatigue syndrome (OR 3.8, $95 \%$ CI 2·2-6.7). Gulf War veterans were also approximately three and a half times more likely than non-Gulf veterans to report multiple chemical sensitivity or chronic multi-symptom illness as defined by CDC. The methodological quality of the studies varied but the later and larger studies were of a high methodological standard with robust sampling strategies, adequate response rates and good adjustment for confounders.

Conclusions. The results support the hypothesis that deployment to the Gulf War is associated with greater reporting of multi-symptom conditions.

\section{INTRODUCTION}

Ever since the end of the Gulf War in 1991, its veterans have expressed concern over a number of health complaints. Symptoms that have been reported by Gulf War veterans include sleep problems, headache, lack of concentration, muscle stiffness and stomach upsets. This has led to the investigation of whether a specific 'Gulf War Syndrome' exists (Haley et al. 1997;

* Address for correspondence: Glyn Lewis, Ph.D., Professor of Psychiatric Epidemiology, University of Bristol, Cotham House, Cotham Hill, Bristol BS6 6JL, UK.

(Email: Glyn.Lewis@bristol.ac.uk)
Ismail et al. 1999). These are common symptoms that often lead to presentation in primary care and hospital settings (Kroenke \& Price, 1993). As a result, many medical specialities have developed and defined various multisymptom syndromes that are medically unexplained. These include chronic fatigue syndrome, fibromyalgia and multiple chemical sensitivity (Wessely et al. 1999). There is still controversy over the nosological status of these syndromes, but the existence of agreed casedefinitions and the associated literature allows for empirical study. 
The measurement of associations between deployment to the Gulf War and later symptomatology is hampered by the necessary reliance on self-report. All measurements of health outcomes are also prone to random error. However, such outcomes, which are difficult to quantify objectively, might be particularly prone both to random measurement error and more importantly to measurement or reporting bias. There have been a number of suggestions that physical exposures such as multiple vaccinations, depleted uranium and oil fires might have caused illness in Gulf War veterans. This study has not focused on this question because most research into illness in Gulf War veterans began some years after the conflict ended and so it was difficult to establish exposure data without introducing bias.

This paper aims to identify and summarize the findings from studies that have compared the prevalence of chronic fatigue syndrome, multiple chemical sensitivity, Centers for Disease Control and Prevention (CDC)-defined chronic multi-symptom illness, fibromyalgia or the specific individual symptoms of fatigue and numbness in Gulf War veterans and an unexposed comparison group. We further aimed to critically assess the methodological quality of the individual studies. We have chosen to carry out a systematic review because of the advantages of this methodology in reducing bias and aiding interpretation of the findings (Lewis et al. 1997).

\section{METHOD}

\section{Searching}

The methods employed in the systematic review have been described in detail in another paper (Stimpson et al. 2003) and are merely summarized here. In total, 5387 studies from the period January 1990 to May 2001 were identified for possible inclusion by searching through databases (including EMBASE, Medline, ASSIA, SIGLE, PsycINFO, CancerLit and HealthStar, Current Contents, CINAHL and Biological Abstracts) and websites and by contacting researchers in the field. Studies were eligible for inclusion if they contained data on military, medical or peace-keeping personnel who were deployed to the Gulf War together with a comparison group which differed in its level of exposure. Abstracts of 2296 references that remained eligible were examined by two members of the research team. Studies were excluded if they measured simulated exposures, if they measured non-health-related outcomes or if the subjects were inhabitants of the Persian Gulf rather than deployed military personnel.

All identified papers that fulfilled the prestated inclusion criteria were categorized by health outcome. Fifty-six studies entered the category of symptomatology. Since the task of systematically reviewing the association between any symptom and any exposure would be too great and would not provide a digestible summary, we decided to focus on a limited number of important outcomes. These specific outcomes were chronic fatigue syndrome, multiple chemical sensitivity, CDC-defined chronic multi-symptom illness, fibromyalgia, or symptoms of either fatigue or numbness and tingling. Eighteen of the 56 papers did not include any of these outcomes. We further excluded those references that only compared exposure histories between Gulf War veterans $(n=8)$, and studies which either presented data as a factor analysis or which included an inappropriate control group for the purposes of this review, e.g. comparison of ill Gulf War veterans and healthy community controls $(n=14)$.

An updated search of the literature from January 2001 to May 2004 was completed which identified 538 references. Of databases searched in 2001, CancerLit and HealthStar are now incorporated into Medline and Dissertation Abstracts \& Health and Psychosocial Instruments are not available. Two databases not searched in 2001, the Web of Knowledge Databases, Science Citation Index and Social Science Citation Index were included in this updated search. Of 538 potentially relevant references, 105 were selected from the abstract (or title if no abstract) that could be research studies with a comparison group. Seven papers that fulfilled the inclusion criteria and which contained data relating to the specified outcomes were identified. Therefore this review summarizes the findings from 23 references which compared Gulf War veterans with non-Gulf veterans (Sutker et al. 1993; Iowa Persian Gulf Study Group, 1997; Bell et al. 1998; Fukuda et al. 1998; Goss Gilroy Inc., 1998; Proctor et al. 1998, 2001, 
Table 1. Characteristics of studies that have investigated the association between deployment to the Gulf War and multi-symptom conditions amongst veterans

\begin{tabular}{|c|c|c|c|c|c|}
\hline First-named author & Study design & Sample & Study period & Ascertainment & Confounding \\
\hline Sutker, 1993 & $\begin{array}{l}\text { Questionnaire } \\
\text { administered } \\
\text { by VA staff }\end{array}$ & $\begin{array}{l}215 \mathrm{GWV} \\
44 \mathrm{NGV} \\
\text { Sampled from } 5 \text { National } \\
\text { Guard and Army Reserve units } \\
\text { as part of debriefing programme }\end{array}$ & $\begin{array}{l}\text { 4-10 months after return from } \\
\text { Operation Desert Shield/Storm }\end{array}$ & $\begin{array}{l}70 \% \text { GWV (306 eligible) } \\
\text { Number of eligible NGVs } \\
\text { unclear }\end{array}$ & \\
\hline $\begin{array}{l}\text { Iowa Group, 1997, } \\
\text { (Black, 2000), } \\
\text { (Doebbeling, 2000) }\end{array}$ & $\begin{array}{l}\text { Cross-sectional } \\
\text { telephone } \\
\text { interview survey }\end{array}$ & $\begin{array}{l}1896 \text { GWV } \\
1799 \text { NGV } \\
\text { DoD Manpower Data Center } \\
\text { used to create a stratified random } \\
\text { sample from } 28968 \text { military } \\
\text { personnel from Iowa }\end{array}$ & Sept. 1995-May 1996 & $\begin{array}{l}78 \cdot 3 \% \text { GWV ( } 2421 \text { eligible } \\
73 \% \text { NGV ( } 2465 \text { eligible) } \\
\text { Those who were regulars, } \\
\text { enlisted, navy or coast guard, } \\
\text { aged up to } 25 \text { years and black } \\
\text { or other ethnic background } \\
\text { less likely to participate }\end{array}$ & $\begin{array}{l}\text { Analysis accounted for } \\
\text { sampling design }\end{array}$ \\
\hline Bell, 1998 & $\begin{array}{l}\text { Cross-sectional } \\
\text { telephone survey }\end{array}$ & $\begin{array}{l}24 \mathrm{GWV} \\
17 \mathrm{NGV} \\
\text { Random sample of } 100 \text { veterans } \\
\text { enrolled at Tucson VA medical } \\
\text { center }\end{array}$ & Autumn 1996-Spring 1997 & $\begin{array}{l}759 \text { GWV eligible } \\
1756 \text { NGV eligible } \\
86 \% \text { GWV }(24 / 28) \\
3 \% \text { of total eligible } \\
85 \% \text { NGV }(17 / 20) \\
1 \% \text { of total eligible }\end{array}$ & \\
\hline Fukuda, 1998 & Cross-sectional survey & $\begin{array}{l}1163 \mathrm{GWV} \\
2560 \text { NGV } \\
\text { Sampled from 2 Air National } \\
\text { Guard units Pennsylvania, 1 Air } \\
\text { Force Reserve unit Florida, } \\
1 \text { active duty air force unit } \\
\text { Florida }\end{array}$ & Jan.-Mar. 1995 & $\begin{array}{l}6151 \text { eligible } \\
\text { Unit response rate } 35-73 \%\end{array}$ & \\
\hline Goss Gilroy, 1998 & Cross-sectional survey & $\begin{array}{l}3113 \text { Canadian GWV } \\
3439 \text { Canadian NGV } \\
\text { Sampled from Department of } \\
\text { National Defence human } \\
\text { resources data files }\end{array}$ & June-Sept. 1997 & $\begin{array}{l}73 \cdot 0 \% \text { GWV (4262 eligible) } \\
60 \cdot 3 \% \text { NGV (5699 eligible) }\end{array}$ & $\begin{array}{l}\text { NGVs matched on sex, age } \\
\text { group and regular/reserve } \\
\text { status }\end{array}$ \\
\hline Proctor, 1998 & Cohort study & $\begin{array}{l}220 \mathrm{GWV} \text { from Fort Devens } \\
73 \mathrm{GWV} \text { from New Orleans } \\
50 \text { Germany deployed veterans }\end{array}$ & Spring 1994-Autumn 1996 & $\begin{array}{l}51 \% \text { Fort Devens } \\
\text { (353 sampled, } 2949 \text { eligible) } \\
38 \% \text { New Orleans } \\
\text { (194 sampled, } 928 \text { eligible) } \\
51 \% \text { Germany deployed }\end{array}$ & $\begin{array}{l}\text { Analysis accounted for } \\
\text { sampling design }\end{array}$ \\
\hline Proctor, 2001 & As Proctor, 1998 & $\begin{array}{l}180 \text { GWV (Fort Devens) } \\
46 \text { Germany deployed veterans }\end{array}$ & As Proctor, 1998 & As Proctor, 1998 & As Proctor, 1998 \\
\hline
\end{tabular}


Table 1 (cont.)

\begin{tabular}{|c|c|c|c|c|c|}
\hline First-named author & Study design & Sample & Study period & Ascertainment & Confounding \\
\hline Gray, 1999 & Cross-sectional survey & $\begin{array}{l}527 \mathrm{GWV} \\
970 \mathrm{NGV} \\
\text { All active-duty Seabees who } \\
\text { remained in service after ODS } \\
\text { and were serving in } 1 \text { of } 2 \text { large } \\
\text { Seabee Centres (California, } \\
\text { Mississippi) }\end{array}$ & Sept. 1994-June 1995 & $\begin{array}{l}\text { Total eligible unknown } \\
\text { Unit response rate } 26-71 \%\end{array}$ & \\
\hline $\begin{array}{l}\text { Ishoy, 1999, } \\
\text { (Proctor, 2003) }\end{array}$ & Cross-sectional survey & $\begin{array}{l}686 \mathrm{GWV} \\
231 \mathrm{NGV} \\
\text { Selected from Danish Armed } \\
\text { Forces personnel database. } \\
\text { Proctor (2003) used subset of } \\
\text { original study: } \\
143 \mathrm{GWV} \\
72 \mathrm{NGV}\end{array}$ & Feb. 1997-Jan. 1998 & $\begin{array}{l}83 \cdot 6 \% \text { GWV (821 eligible) } \\
57 \cdot 8 \% \text { NGV (400 sampled) }\end{array}$ & $\begin{array}{l}\text { Controls matched for gender, } \\
\text { age and profession }\end{array}$ \\
\hline $\begin{array}{r}\text { Unwin, 1999, } \\
\text { (Reid, 2001) }\end{array}$ & $\begin{array}{l}\text { Cross-sectional } \\
\text { postal survey }\end{array}$ & $\begin{array}{l}2735 \text { GWV } \\
2393 \text { Bosnia veterans } \\
2422 \text { Era controls } \\
\text { Random sample taken from the } \\
\text { UK MoD database } \\
\text { Unwin: servicemen only } \\
\text { Reid: servicemen and women }\end{array}$ & Aug. 1997-Nov. 1998 & $\begin{array}{l}70 \cdot 4 \% \text { GWV (4250 eligible) } \\
61 \cdot 9 \% \text { Bosnia ( } 4250 \text { eligible) } \\
62.9 \% \text { Era (4246 eligible) }\end{array}$ & $\begin{array}{l}\text { Sample was stratified by service, } \\
\text { status, sex, age, rank and fitness }\end{array}$ \\
\hline Unwin, 2002 & As Unwin, 1999 & $\begin{array}{l}236 \text { GWV } \\
217 \text { Bosnia veterans } \\
192 \text { Era controls } \\
\text { Servicewomen only }\end{array}$ & As Unwin, 1999 & $\begin{array}{l}74 \cdot 0 \% \text { GWV } \\
70 \cdot 2 \% \text { Bosnia } \\
69 \cdot 6 \% \text { Era }\end{array}$ & As Unwin, 1999 \\
\hline Hotopf, 2003 & As Unwin, 1999 & $\begin{array}{l}1089 \mathrm{GWV} \\
638 \text { Bosnia veterans } \\
643 \text { Era controls }\end{array}$ & 4-year follow-up (2001) & $\begin{array}{l}71 \cdot 7 \% \text { GWV } \\
66 \cdot 2 \% \text { Bosnia } \\
58 \cdot 4 \% \text { Era } \\
\text { Non-responders to follow-up } \\
\text { were more likely to be male, } \\
\text { younger, unmarried and report } \\
\text { poorer physical health at baseline }\end{array}$ & $\begin{array}{l}\text { As Unwin, } 1999 . \\
\text { Follow-up sample stratified by } \\
\text { baseline fatigue }\end{array}$ \\
\hline $\begin{array}{l}\text { Kang, 2000, } \\
\text { (Kang, 2003) }\end{array}$ & $\begin{array}{l}\text { Population-based } \\
\text { survey }\end{array}$ & $\begin{array}{l}11441 \text { GWV } \\
9476 \text { NGV } \\
\text { Stratified random sample taken } \\
\text { from the DoD Manpower Data } \\
\text { Center }\end{array}$ & 1995-1997 & $\begin{array}{l}76 \cdot 3 \% \text { GWV (15000 eligible) } \\
632 \% \text { NGV (15000 eligible) } \\
\text { Non-responders were more } \\
\text { likely to be younger, unmarried, } \\
\text { non-white and enlisted }\end{array}$ & $\begin{array}{l}\text { Analysis accounted for } \\
\text { sampling design }\end{array}$ \\
\hline Steele, 2000 & $\begin{array}{l}\text { Population-based } \\
\text { telephone survey }\end{array}$ & $\begin{array}{l}1548 \text { GWV } \\
482 \text { NGV } \\
\text { DoD Manpower Data Center } \\
\text { used to create a stratified random } \\
\text { sample from } 16566 \text { military } \\
\text { personnel from Kansas }\end{array}$ & Feb.-Aug. 1998 & $\begin{array}{l}65 \% \text { response ( } 3138 \text { eligible) } \\
\text { Overall, Gulf and female } \\
\text { veterans were more likely } \\
\text { to respond }\end{array}$ & \\
\hline
\end{tabular}



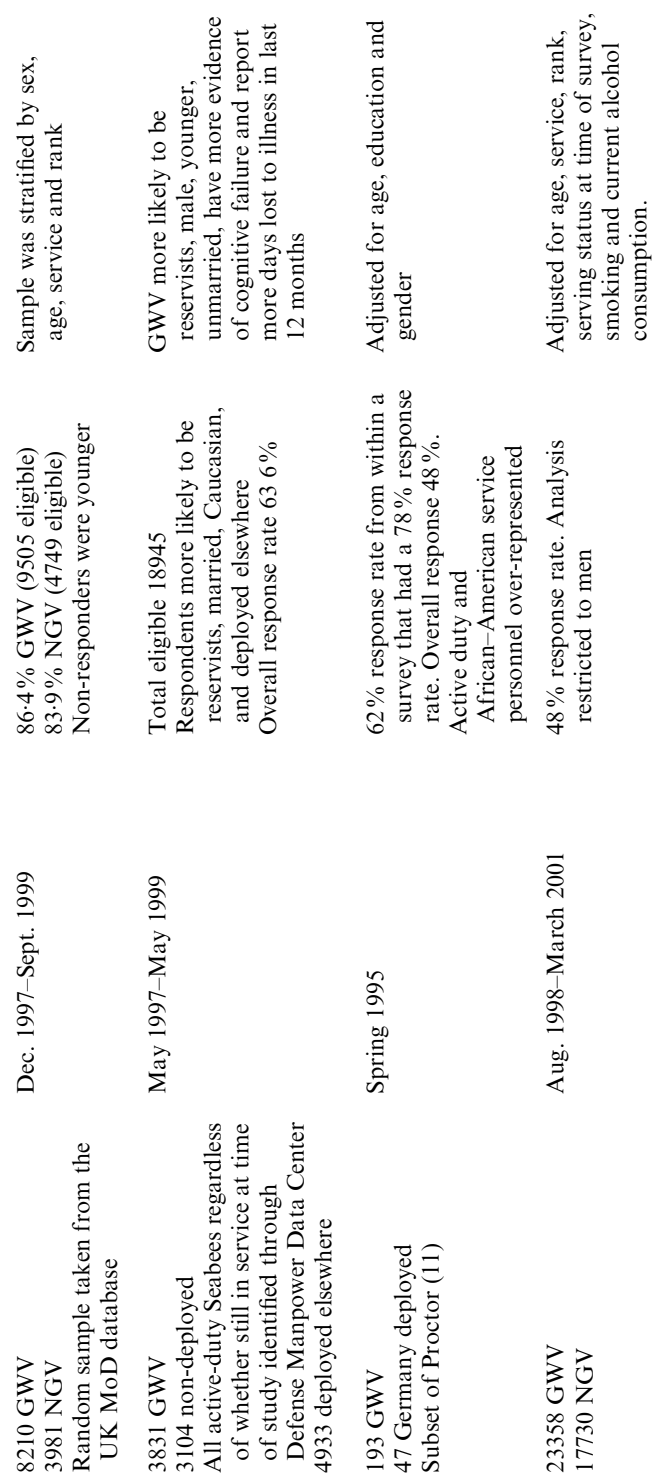

2003; Gray et al. 1999; Ishoy et al. 1999; Unwin et al. 1999; Black et al. 2000; Doebbeling et al. 2000; Kang et al. 2000, 2003; Steele, 2000; Cherry et al. 2001; Reid et al. 2001; White et al. 2001; Gray et al. 2002; Unwin et al. 2002; Hotopf et al. 2003; Simmons et al. 2004). These non-Gulf veterans may or may not have been deployed elsewhere on active duty.

\section{Data extraction}

Data relating to the studies' main hypotheses and to methodological quality were extracted independently by two members of the research team onto pre-designed data extraction forms. Some studies did not provide sufficient data to provide odds ratios (ORs) that were used as our outcome measure. Information on methodological quality of the individual studies included the statistical power, the potential of selection bias in the sampling of subjects and in the response rate, the potential bias in the measurement of outcomes, and the availability of data on confounders and the controlling for such variables in each study. We did not summarize the quality by creating a score as this approach has been criticized as giving equal weight to different aspects of methodology and relying heavily upon the quality of reporting rather than the quality of the original study (Juni et al. 2001).

\section{Statistical analysis}

A summary OR was calculated with a randomeffects model using the DerSimonian \& Laird method (1986). The estimate of heterogeneity between studies was taken from the inverse variance fixed-effects model. All analyses were performed using the 'metan' (Bradburn et al. 1998) command in STATA version 6 (Stata Corporation, College Station, TX, USA).

We chose to use this approach because of our a priori view that the studies were inherently heterogeneous. Using a ratio measure should reduce the heterogeneity resulting from different thresholds of case-definitions. A random-effects model assumes that the studies in a metaanalysis are randomly sampled from a distribution of effect sizes so the procedure estimates the mean of this distribution. In contrast, a fixed-effects model assumes that all the studies are sampled from a population with a single 
effect size which all studies are estimating. There was insufficient data to further investigate heterogeneity.

\section{RESULTS}

We identified 23 references to 14 primary study samples which compared the prevalence of multi-symptom conditions in both Gulf War veterans and non-Gulf veterans. Black et al. (2000) and Doebbeling et al. (2000) utilized the sample described in the Iowa study (Iowa Persian Gulf Study Group, 1997); the study sample described by Proctor et al. (2001) and White et al. (2001) was a smaller subset of that described by Proctor et al. (1998); the sample initially described by Unwin et al. (1999; servicemen only) was later utilized by Reid et al. (2001; servicemen and women), Unwin et al. (2002; servicewomen only) and Hotopf et al. (2003; 4-year follow-up study); Kang et al. reported data on the same study sample both in 2000 and in 2003. Although both publications by Gray et al. (1999, 2002) included a sample of active-duty Seabees, these were separate studies with different sampling strategies and fieldwork dates.

Table 1 summarizes the methodology used in creating these 14 study samples. Nine samples consisted of American Gulf War veterans, three samples included British veterans, one sample included Canadian veterans and one sample included Danish veterans involved in UN peacekeeping and humanitarian operations. Sutker et al. (1993) were the only authors to assess multi-symptom conditions soon after returning from the war arena. All other studies assessed these conditions from 1994 onwards. All studies relied on self-reported measurement of symptoms. Three studies investigated the test-retest reliability of their measures. The Iowa Group (1997) reported kappas between $0 \cdot 35$ and $0 \cdot 79$. Gray et al. (1999) retested a subsample of subjects between 5 and 9 months later and reported kappas varying between 0.01 and $0 \cdot 86$. Gray et al. (2002) also tested the reliability of self-reported physician-diagnosed medical conditions in 519 subjects retested 6 months apart and reported a kappa of $0 \cdot 6$. These studies cannot investigate the issue of bias and their measure of reliability will be underestimates as symptoms may also have changed in the intervening period.

Table 2 summarizes the results of the 10 references that investigated the association between Gulf deployment and chronic fatigue. There was variation in the length of period prevalence estimated and in the diagnosis of chronic fatigue. Data from seven of the references were entered into the meta-analysis. The summary OR reflected a statistically significant association between deployment to the Gulf War and subsequent reporting of chronic fatigue [OR 3.81, 95\% confidence interval (CI) $2 \cdot 17$ $6 \cdot 71]$. The test for heterogeneity was statistically significant $(p<0 \cdot 001)$.

We identified 16 references (Table 3) that investigated the association between Gulf deployment and symptoms of fatigue. Cherry et al. (2001), White et al. (2001) and Proctor et al. (2003) did not quote prevalence estimates of symptoms, therefore their data cannot provide ORs. Only the study by Sutker et al. (1993) carried out within 10 months of returning from the war reported a non-significant increase in reporting of fatigue, although the CI was wide (OR 1.98, 95\% CI 0.73-5.38). All other studies (Fukuda et al. 1998; Gray et al. 1999; Ishoy et al. 1999; Unwin et al. 1999, 2002; Doebbeling et al. 2000; Kang et al. 2000; Steele, 2000; Proctor et al. 2001; Gray et al. 2002; Hotopf et al. 2003; Simmons et al. 2004) reported a statistically significant association between deployment and symptoms of fatigue. This was summarized by an OR of $3.74 \quad(95 \%$ CI 2.94-4.75) when 12 studies were entered into a meta-analysis using a random-effects model. The test for heterogeneity based on the fixedeffects model was statistically significant $\left(\chi^{2}=59 \cdot 4, \mathrm{df}=6, p<0 \cdot 001\right)$, probably due to the difference in effect sizes demonstrated between Unwin et al. (1999), Kang et al. (2000) and Gray et al. (2002). It was striking that the prevalence of self-reported fatigue was very high amongst British Gulf war veterans, Bosnia veterans and era controls in the study by Unwin et al. (1999, 2002). Hotopf et al. (2003) demonstrated that 4 years later the Gulf War veterans continued to report more fatigue than the comparison military cohorts. This seemed to be largely explained by greater persistence of fatigue symptoms amongst Gulf veterans, but there was also some evidence of higher incidence of fatigue 
Table 2. Studies that have investigated the association between deployment to the Gulf War and chronic fatigue syndrome amongst veterans

\begin{tabular}{|c|c|c|c|c|}
\hline $\begin{array}{l}\text { First-named } \\
\text { author }\end{array}$ & Outcome definition & Prevalence & $\begin{array}{l}\text { OR }(95 \% \mathrm{CI}) \text { in } \\
\text { relation to Gulf } \\
\text { deployment }\end{array}$ & $\begin{array}{l}\% \text { weight in } \\
\text { meta-analysis }\end{array}$ \\
\hline $\begin{array}{l}\text { Iowa Group, } \\
1997\end{array}$ & $\begin{array}{l}\text { Centers for Disease Control and } \\
\text { Prevention (CDC) Chronic } \\
\text { Fatigue Syndrome } \\
\text { Questionnaire and Chalder } \\
\text { et al.'s (1993) Fatigue Scale. } \\
\text { Prevalence } 1 \text { month prior to interview }\end{array}$ & $\begin{array}{l}\text { Regular military } \\
\text { GWV prevalence } 1.0 \% \\
\text { NGV prevalence } 0.2 \% \\
\text { National Guard/Reserves } \\
\text { GWV prevalence } 2.9 \% \\
\text { NGV prevalence } 1.1 \%\end{array}$ & $3 \cdot 15(1 \cdot 60-6 \cdot 20)$ & $15 \cdot 0$ \\
\hline $\begin{array}{l}\text { Goss Gilroy, } \\
1998\end{array}$ & $\begin{array}{l}\text { CDC Chronic Fatigue } \\
\text { Syndrome Questionnaire. } \\
\text { Period of prevalence is unclear }\end{array}$ & $\begin{array}{l}\text { OR chronic fatigue } \\
5 \cdot 27(95 \% \text { CI } 3 \cdot 95-7 \cdot 03)\end{array}$ & & \\
\hline Unwin, 1999 & $\begin{array}{l}\text { Chalder et al.'s Fatigue Scale. } \\
\text { Prevalence } 1 \text { month prior to interview }\end{array}$ & $\begin{array}{l}\text { GWV prevalence } 3.3 \% \\
\text { Bosnia prevalence } 0.8 \% \\
\text { Era prevalence } 0.8 \%\end{array}$ & & \\
\hline Reid, 2001 & $\begin{array}{l}\text { CDC diagnosis derived from } \\
\text { Chalder et al.'s Fatigue Scale } \\
\text { and SF-36. } \\
\text { Prevalence } 1 \text { month prior to interview }\end{array}$ & $\begin{array}{l}\text { GWV prevalence } 2 \cdot 1 \% \\
\text { Era prevalence } 1 \cdot 8 \% \\
\text { Bosnia prevalence } 07 \%\end{array}$ & $1 \cdot 17(0 \cdot 81-1 \cdot 69)$ & $17 \cdot 7$ \\
\hline Unwin, 2002 & $\begin{array}{l}\text { Chalder } \text { et al.'s Fatigue Scale. } \\
\text { Prevalence } 1 \text { month prior to interview }\end{array}$ & $\begin{array}{l}\text { GWV prevalence } 4.7 \% \\
\text { Bosnia prevalence } 0.5 \% \\
\text { Era prevalence } 05 \%\end{array}$ & & \\
\hline Steele, 2000 & $\begin{array}{l}\text { CDC diagnosis derived from } \\
\text { self-reported symptoms and } \\
\text { fatigue characteristics. } \\
\text { Prevalence } 1 \text { year prior to interview }\end{array}$ & $\begin{array}{l}\text { GWV prevalence } 7 \cdot 1 \% \\
\text { NGV prevalence } 0 \cdot 7 \%\end{array}$ & $11 \cdot 04(3 \cdot 49-34 \cdot 93)$ & $10 \cdot 7$ \\
\hline Proctor, 2001 & $\begin{array}{l}\text { CDC diagnosis derived from } \\
\text { self-reported symptoms. } \\
\text { Unknown prevalence period }\end{array}$ & $\begin{array}{l}\text { GWV prevalence } 7 \cdot 5 \% \\
\text { (excluding rule-out } \\
\text { indicators } 2 \cdot 0 \% \text { ) } \\
\text { Germany deployed } \\
\text { prevalence } 0 \%\end{array}$ & $2 \cdot 37(0 \cdot 13-44 \cdot 83)$ & $3 \cdot 1$ \\
\hline Gray, 2002 & $\begin{array}{l}\text { Self-reported physician } \\
\text { diagnosis of chronic fatigue } \\
\text { syndrome, onset after Aug. } 1991\end{array}$ & $\begin{array}{l}\text { GWV prevalence } 5 \cdot 17 \% \\
\text { Deployed elsewhere } \\
\text { prevalence } 0 \cdot 79 \% \\
\text { Non-deployed prevalence } \\
0.68 \%\end{array}$ & $6 \cdot 75(4 \cdot 77-9 \cdot 54)$ & $17 \cdot 9$ \\
\hline Kang, 2003 & $\begin{array}{l}\text { CDC diagnosis derived from } \\
\text { self-reported symptoms. } \\
\text { Prevalence } 1 \text { year and } 1 \text { month } \\
\text { prior to interview }\end{array}$ & $\begin{array}{l}\text { GWV prevalence } 5 \cdot 6 \% \\
\text { NGV prevalence } 1 \cdot 2 \%\end{array}$ & $4.87(5.96-21.92)$ & $18 \cdot 7$ \\
\hline $\begin{array}{l}\text { Simmons, } \\
2004\end{array}$ & $\begin{array}{l}\text { Prevalence of self-reported chronic } \\
\text { fatigue syndrome since } 1990\end{array}$ & $\begin{array}{l}\text { GWV } 0 \cdot 4 \% \\
\text { NGV } 0 \cdot 1 \%\end{array}$ & $3 \cdot 5(2 \cdot 1-5 \cdot 5)$ & $16 \cdot 9$ \\
\hline & & & \multicolumn{2}{|c|}{$\begin{array}{c}\text { Summary OR } 3 \cdot 81(2 \cdot 17-6 \cdot 71) \\
\text { Heterogeneity } \chi^{2}=59 \cdot 4, \mathrm{df}=6, p<0 \cdot 0001\end{array}$} \\
\hline
\end{tabular}

GWV, Gulf War veterans; NGV, non-Gulf veterans.

OR, Odds ratio with confidence intervals in parentheses. Summary OR derived from random-effects model.

Iowa study combines prevalence in regular military and National Guard/Reserves for meta-analysis.

Goss Gilroy not used in meta-analysis since raw numbers not provided. Unwin data not used in meta-analysis to avoid duplication with Reid data. Reid study compares Gulf versus era controls for meta-analysis. Proctor study uses prevalence excluding rule-out indicators for meta-analysis. Gray study compares Gulf versus controls deployed elsewhere for meta-analysis.

in the two deployed groups when compared to the era controls.

Seven references investigated the association between deployment to the Gulf and multiple chemical sensitivity, five of which provided data for the meta-analysis with the study by
Black et al. (2000) and Gray et al. (2002) providing approximately $65 \%$ of the weight to the summary OR (Table 4). The prevalence estimates quoted by Bell et al. (1998) were much higher than those reported in the other studies probably due to the much broader 
Table 3. Studies that have investigated the association between deployment to the Gulf War and symptoms of fatigue amongst veterans

\begin{tabular}{|c|c|c|c|c|}
\hline $\begin{array}{l}\text { First-named } \\
\text { author }\end{array}$ & Outcome definition & Prevalence & $\begin{array}{l}\text { OR in relation to } \\
\text { Gulf deployment }\end{array}$ & $\begin{array}{l}\% \text { weight in } \\
\text { meta-analysis }\end{array}$ \\
\hline Sutker, 1993 & Current fatigue/lack of energy & $\begin{array}{l}\text { GWV prevalence } 20 \% \\
\text { NGV prevalence } 11 \%\end{array}$ & $1 \cdot 98(0 \cdot 73-5 \cdot 38)$ & $3 \cdot 7$ \\
\hline Fukuda, 1998 & Current fatigue & $\begin{array}{l}\text { GWV prevalence } 43 \% \\
\text { NGV prevalence } 17 \%\end{array}$ & $3 \cdot 69(3 \cdot 16-4 \cdot 31)$ & $9 \cdot 9$ \\
\hline Gray, 1999 & $\begin{array}{l}\text { Unusual fatigue } \\
\geqslant 1 \text { month since July } 1990\end{array}$ & $\begin{array}{l}\text { GWV prevalence } 20 \cdot 1 \% \\
\text { NGV prevalence } 5 \cdot 4 \%\end{array}$ & $4 \cdot 44(3 \cdot 13-6 \cdot 32)$ & $8 \cdot 5$ \\
\hline Ishoy, 1999 & $\begin{array}{l}\text { Abnormal feeling of fatigue } \\
\text { during preceding } 12 \text { months }\end{array}$ & $\begin{array}{c}\text { Symptom after Aug. } 1990 \\
\text { GWV prevalence } 26.4 \% \\
\text { NGV prevalence } 10 \cdot 8 \% \\
\text { Symptom before Aug. } 1990 \\
\text { GWV prevalence } 1.9 \% \\
\text { NGV prevalence } 1.7 \%\end{array}$ & $2 \cdot 95(1 \cdot 89-4 \cdot 62)$ & $7 \cdot 6$ \\
\hline Unwin, 1999 & Current fatigue (past month) & $\begin{array}{l}\text { GWV prevalence } 50 \cdot 7 \% \\
\text { Bosnia prevalence } 26 \cdot 3 \% \\
\text { Era prevalence } 27 \cdot 7 \%\end{array}$ & $2 \cdot 68(2 \cdot 40-3 \cdot 00)$ & $10 \cdot 1$ \\
\hline Unwin, 2002 & Current fatigue (past month) & $\begin{array}{l}\text { GWV prevalence } 59 \cdot 4 \% \\
\text { Bosnia prevalence } 31 \cdot 6 \% \\
\text { Era prevalence } 34 \cdot 7 \%\end{array}$ & $1 \cdot 9(1 \cdot 1-3 \cdot 2)$ & $8 \cdot 1$ \\
\hline Hotopf, 2003 & Current fatigue & $\begin{array}{l}\text { GWV prevalence } 43 \cdot 4 \% \\
\text { Bosnia prevalence } 32 \cdot 7 \% \\
\text { Era prevalence } 22 \cdot 0 \%\end{array}$ & & \\
\hline Doebbeling, 2000 & $\begin{array}{l}\text { Period of extreme fatigue } \\
\text { every day or almost every } \\
\text { day in past year }\end{array}$ & $\begin{array}{l}\text { GWV prevalence } 23 \% \\
\text { NGV prevalence } 9 \%\end{array}$ & $3 \cdot 02(2 \cdot 49-3 \cdot 66)$ & $9 \cdot 7$ \\
\hline Kang, 2000 & $\begin{array}{l}\text { Fatigue } \\
\text { Period of prevalence unclear }\end{array}$ & $\begin{array}{l}\text { GWV prevalence } 38 \% \\
\text { NGV prevalence } 15 \%\end{array}$ & $3 \cdot 47(3 \cdot 25-3 \cdot 72)$ & $10 \cdot 3$ \\
\hline Steele, 2000 & Period of fatigue in past year & $\begin{array}{l}\text { GWV prevalence } 36 \% \\
\text { NGV prevalence } 12 \%\end{array}$ & $4 \cdot 14(3 \cdot 01-5 \cdot 68)$ & $8 \cdot 7$ \\
\hline Proctor, 2001 & $\begin{array}{l}\text { Current fatigue not meeting } \\
\text { CDC diagnosis }\end{array}$ & $\begin{array}{l}\text { GWV prevalence } 29 \cdot 4 \% \\
\text { Germany deployed prevalence } 8 \cdot 7 \%\end{array}$ & $4 \cdot 38(1 \cdot 50-12 \cdot 83)$ & $3 \cdot 4$ \\
\hline Cherry, 2001 & $\begin{array}{l}\text { Tiredness (past month) } \\
\text { Visual analogue scale }\end{array}$ & $\begin{array}{l}\text { GWV mean score }=8 \cdot 3 \\
\text { NGV mean score }=5 \cdot 0\end{array}$ & & \\
\hline Gray, 2002 & Unusual fatigue in past year & $\begin{array}{l}\text { GWV prevalence } 38 \cdot 95 \% \\
\text { Deployed elsewhere prevalence } 14 \cdot 13 \% \\
\text { Non-deployed prevalence } 13.43 \%\end{array}$ & $3 \cdot 87(3 \cdot 50-4 \cdot 29)$ & $10 \cdot 1$ \\
\hline White, 2001 & Profile of Mood States & $\begin{array}{l}\text { GWV } t \text { score } 47 \cdot 4 \text {, S.E. }=0 \cdot 62 \\
\text { NGV } t \text { score } 42 \cdot 1 \text {, S.E. }=0 \cdot 84 \\
\text { Difference } p=0 \cdot 001\end{array}$ & & \\
\hline Simmons, 2004 & Self-reported general fatigue & $\begin{array}{l}\text { GWV prevalence } 10 \cdot 8 \% \\
\text { NGV prevalence } 1 \cdot 2 \%\end{array}$ & $9 \cdot 6(8 \cdot 3-11 \cdot 1)$ & $10 \cdot 0$ \\
\hline Proctor, 2003 & $\begin{array}{l}\text { Profile of Mood States } \\
\text { (Raw scores) }\end{array}$ & $\begin{array}{l}\text { GWV } 6 \cdot 3, \text { S.E. }=0 \cdot 4 \\
\text { NGV } 4 \cdot 6, \text { S.E. }=0 \cdot 5 \\
\text { Difference } p=0 \cdot 005\end{array}$ & $\begin{array}{r}\text { Summary OR } 3 . \\
\text { Heterogeneity } \chi^{2}=241 .\end{array}$ & $\begin{array}{l}94-4 \cdot 75) \\
=11, p<0 \cdot 0001\end{array}$ \\
\hline
\end{tabular}

GWV, Gulf War veterans; NGV, non-Gulf veterans.

OR, Odds ratio with confidence intervals in parentheses. Summary OR derived from random-effects model.

Unwin studies compare Gulf versus era controls for meta-analysis. Hotopf data not used in meta-analysis to avoid duplication with Unwin data. Gray study compares Gulf versus controls deployed elsewhere for meta-analysis.

definition of the outcome. Overall, the odds of reporting multiple chemical sensitivity was approximately three and a half times greater amongst veterans deployed to the Gulf War (OR 3.56, 95\% CI 2.03-6.24). The test for heterogeneity was of borderline statistical significance $(p=0 \cdot 05)$.

All five studies that investigated chronic multi-symptom illness used the CDC diagnosis (Table 5). Prevalence estimates varied greatly 
Table 4. Studies that have investigated the association between deployment to the Gulf War and multiple chemical sensitivity amongst veterans

\begin{tabular}{|c|c|c|c|c|}
\hline $\begin{array}{l}\text { First-named } \\
\text { author }\end{array}$ & Outcome definition & Prevalence & $\begin{array}{l}\text { OR }(95 \% \mathrm{CI}) \text { in } \\
\text { relation to Gulf } \\
\text { deployment }\end{array}$ & $\begin{array}{l}\% \text { weight in } \\
\text { meta-analysis }\end{array}$ \\
\hline Bell, 1998 & $\begin{array}{l}\text { Consider self especially sensitive to } \\
\text { certain chemicals currently }\end{array}$ & $\begin{array}{l}\text { GWV prevalence } 62 \cdot 5 \% \\
\text { NGV prevalence } 41 \cdot 2 \%\end{array}$ & $2 \cdot 38(0 \cdot 67-8 \cdot 49)$ & $13 \cdot 1$ \\
\hline $\begin{array}{l}\text { Goss Gilroy, } \\
1998\end{array}$ & $\begin{array}{l}\text { Report illness from chemical sensitivity, } \\
\geqslant 2 \text { incitants, } \geqslant 2 \text { organ system } \\
\text { symptoms, behaviour change }\end{array}$ & $\begin{array}{l}\text { OR multiple chemical sensitivity } \\
\text { by Gulf deployment } \\
4 \cdot 01(95 \% \text { CI } 2 \cdot 43-6 \cdot 62)\end{array}$ & & \\
\hline Unwin, 1999 & $\begin{array}{l}\text { Shortened version of Kipen et al.'s (1995) } \\
\text { measurement of symptoms of possible } \\
\text { chemical sensitivity }\end{array}$ & $\begin{array}{l}\text { GWV prevalence } 0 \cdot 8 \% \\
\text { Bosnia prevalence } 0 \cdot 4 \% \\
\text { Era prevalence } 0 \cdot 3 \%\end{array}$ & & \\
\hline Reid, 2001 & $\begin{array}{l}\text { Symptoms reported } \geqslant 3 \text { organ sites } \\
\text { including CNS, duration } \geqslant 3 \text { months, } \\
\text { sensitivity to } \geqslant 4 \text { substances from } \\
\text { shortened version of Kipen } \text { et al.'s } \\
\text { (1995) list }\end{array}$ & $\begin{array}{l}\text { GWV prevalence } 1 \cdot 3 \% \\
\text { Bosnia prevalence } 0 \cdot 3 \% \\
\text { Era prevalence } 0 \cdot 2 \%\end{array}$ & $6 \cdot 89(2 \cdot 73-17 \cdot 36)$ & $19 \cdot 3$ \\
\hline Black, 2000 & $\begin{array}{l}\text { Report illness from chemical sensitivity, } \\
\geqslant 2 \text { incitants, } \geqslant 2 \text { organ system } \\
\text { symptoms, impairment or behaviour } \\
\text { change }\end{array}$ & $\begin{array}{l}\text { GWV prevalence } 5 \cdot 41 \% \\
\text { NGV prevalence } 2 \cdot 55 \%\end{array}$ & $2 \cdot 19(1 \cdot 54-3 \cdot 12)$ & $35 \cdot 0$ \\
\hline Proctor, 2001 & $\begin{array}{l}>1 \text { symptom that began after service, } \\
\geqslant 2 \text { organ system symptoms, } \\
\text { symptoms triggered by low-level } \\
\text { chemical exposure, symptoms that } \\
\text { cannot be explained by any diagnosis }\end{array}$ & $\begin{array}{l}\text { GWV prevalence } 2 \cdot 9 \% \\
\text { Germany deployed prevalence } 0 \%\end{array}$ & $2 \cdot 91(0 \cdot 16-53 \cdot 66)$ & $3 \cdot 4$ \\
\hline Gray, 2002 & $\begin{array}{l}\text { Self-reported physician diagnosis of } \\
\text { multiple chemical sensitivity, onset } \\
\text { after Aug. } 1991\end{array}$ & $\begin{array}{l}\text { GWV prevalence } 1 \cdot 62 \% \\
\text { Deployed elsewhere } \\
\text { prevalence } 0 \cdot 32 \% \\
\text { Non-deployed prevalence } 0.39 \%\end{array}$ & $5 \cdot 06(2 \cdot 91-8 \cdot 77)$ & $29 \cdot 2$ \\
\hline & & & \multicolumn{2}{|c|}{$\begin{array}{c}\text { Summary OR } 3 \cdot 56(2 \cdot 03-6 \cdot 24) \\
\text { Heterogeneity } \chi^{2}=9 \cdot 7, \mathrm{df}=4, p=0 \cdot 05\end{array}$} \\
\hline
\end{tabular}

GWV, Gulf War veterans; NGV, non-Gulf veterans.

OR, Odds ratio with confidence intervals in parentheses. Summary OR derived from random-effects model.

Goss Gilroy data not used in meta-analysis since raw numbers not provided. Unwin data not used in meta-analysis to avoid duplication with Reid data. Reid study compares Gulf versus era controls for meta-analysis. Gray study compares Gulf versus controls deployed elsewhere for meta-analysis.

depending on the severity of the illness. For those studies that reported prevalence of severe and moderate illness separately the estimates were summed to provide one OR for each study. Although Gulf deployment was strongly associated with chronic multi-symptom illness (OR $3 \cdot 62$, 95\% CI $2 \cdot 75-4 \cdot 76$ ), the test for heterogeneity between studies was highly statistically significant $(p<0 \cdot 001)$.

There were six studies which reported prevalence of numbness or tingling sensations (Proctor et al. 1998; Fukuda et al. 1998; Ishoy et al. 1999; Unwin et al. 1999; Kang et al. 2000; Cherry et al. 2001). Deployment to the Gulf War was associated with a two-fold increase in odds of reporting such sensations (OR 2.37, $95 \%$ CI $1 \cdot 80-3 \cdot 12$ ). The variation in definition of outcome and period of prevalence across studies might have led to the statistically significant heterogeneity $\left(\chi^{2}=35 \cdot 5, \quad \mathrm{df}=4\right.$, $p<0.001)$.

Only two studies reported the association between Gulf deployment and fibromyalgia. The Iowa study (1997) reported a 1-month prevalence of $18.2 \%$ amongst Gulf War regular military veterans and a prevalence of $9 \cdot 2 \%$ amongst non-Gulf regular military veterans. Goss Gilroy (1998) did not quote prevalence figures, but reported an OR of 1.81 (95\% CI $1 \cdot 55-2 \cdot 13)$ with respect to Gulf deployment.

\section{DISCUSSION}

This systematic review supports the hypothesis that deployment to the Gulf War is associated with greater reporting of multi-symptom 
Table 5. Studies that have investigated the association between deployment to the Gulf War and defined 'chronic multi-symptom illness' amongst veterans

\begin{tabular}{|c|c|c|c|c|}
\hline $\begin{array}{l}\text { First-named } \\
\text { author }\end{array}$ & Outcome definition & Prevalence & $\begin{array}{l}\text { OR }(95 \% \text { CI }) \text { in } \\
\text { relation to Gulf } \\
\text { deployment }\end{array}$ & $\begin{array}{l}\% \text { weight in } \\
\text { meta-analysis }\end{array}$ \\
\hline Fukuda, 1998 & $\begin{array}{l}\text { CDC Chronic multi-symptom illness: } \\
\geqslant 1 \text { symptom ( } 6 \text { months) from } \geqslant 2 \\
\text { of following: fatigue, mood and } \\
\text { cognition, musculoskeletal }\end{array}$ & $\begin{array}{l}\text { Severe } \\
\text { GWV prevalence } 6.0 \% \\
\text { NGV prevalence } 0.7 \% \\
\text { Mild to moderate } \\
\text { GWV prevalence } 39 \% \\
\text { NGV prevalence } 14 \%\end{array}$ & $4 \cdot 76(4 \cdot 05-5 \cdot 58)$ & $24 \cdot 8$ \\
\hline Unwin, 1999 & $\begin{array}{l}\text { CDC Chronic multi-symptom illness: } \\
\geqslant 1 \text { symptom ( } 6 \text { months) from } \geqslant 2 \\
\text { of following: fatigue, mood and } \\
\text { cognition, musculoskeletal }\end{array}$ & $\begin{array}{l}\text { GWV prevalence } 61 \cdot 9 \% \\
\text { Bosnia prevalence } 36 \cdot 8 \% \\
\text { Era prevalence } 36 \cdot 4 \%\end{array}$ & $2 \cdot 84(2 \cdot 54-3 \cdot 16)$ & $26 \cdot 0$ \\
\hline Unwin, 2002 & CDC Chronic multi-symptom illness & $\begin{array}{l}\text { GWV prevalence } 63 \cdot 8 \% \\
\text { Bosnia prevalence } 36 \cdot 6 \% \\
\text { Era prevalence } 34 \cdot 7 \%\end{array}$ & $3 \cdot 33(2 \cdot 23-4 \cdot 96)$ & $17 \cdot 3$ \\
\hline Steele, 2000 & $\begin{array}{l}\text { CDC Chronic multi-symptom illness: } \\
\geqslant 1 \text { symptom ( } 6 \text { months) from } \geqslant 2 \\
\text { of cognition, musculoskeletal }\end{array}$ & $\begin{array}{l}\text { GWV prevalence } 47 \cdot 2 \% \\
\text { NGV prevalence } 19 \cdot 8 \%\end{array}$ & $3 \cdot 63(2 \cdot 81-4 \cdot 68)$ & $21 \cdot 9$ \\
\hline Proctor, 2001 & $\begin{array}{l}\text { CDC Chronic multi-symptom illness: } \\
\geqslant 1 \text { symptom ( } 6 \text { months) from } \geqslant 2 \\
\text { of following: fatigue, mood and } \\
\text { cognition, musculoskeletal }\end{array}$ & $\begin{array}{l}\text { GWV prevalence } 65 \cdot 3 \% \\
\text { Germany deployed prevalence } 32 \cdot 6 \% \\
\text { Severe } \\
\text { GWV prevalence } 31 \cdot 9 \% \\
\text { NGV prevalence } 4 \cdot 4 \% \\
\text { Mild to moderate } \\
\text { GWV prevalence } 33 \cdot 4 \% \\
\text { NGV prevalence } 28.3 \%\end{array}$ & $3.93(1.98-7 \cdot 83)$ & $10 \cdot 0$ \\
\hline & & & \multicolumn{2}{|c|}{$\begin{array}{c}\text { Summary OR } 3.62(2 \cdot 75-4 \cdot 76) \\
\text { Heterogeneity } \chi^{2}=28 \cdot 0, \mathrm{df}=4, p<0 \cdot 001\end{array}$} \\
\hline
\end{tabular}

GWV, Gulf War veterans; NGV, non-Gulf veterans.

OR, Odds ratio with confidence intervals in parentheses. Summary OR derived from random-effects model.

Fukuda study sums prevalence of severe and mild-moderate symptoms for meta-analysis. Unwin study compares Gulf versus era controls for meta-analysis. Proctor study sums prevalence of severe and mild-moderate symptoms for meta-analysis.

conditions. Each of the primary studies consistently demonstrated that a greater proportion of Gulf war veterans than non-Gulf veterans reported either a defined multi-symptom condition or individual symptoms of fatigue and numbness. Gulf deployment was most strongly associated with chronic fatigue, with Gulf War veterans being almost four times more likely than non-Gulf veterans to report such symptoms. The odds of reporting multiple chemical sensitivity or chronic multi-symptom illness as defined by CDC were also approximately three and a half times greater amongst Gulf War veterans. The evidence for an association with fibromyalgia was limited to the results from only two studies.

We used a random-effects model in the meta-analyses to estimate summary ORs. This procedure estimates the mean of the distribution of possible effect sizes. We also quote a test for heterogeneity based on a fixed-effects model. There is strong evidence that there is not a single effect size underlying the variation in results of these studies. There are a number of reasons why this should be so, including variation in the case-definition used in the different studies as well as the difference in sampling and between the nations. However, all the studies reported an association between Gulf deployment and multi-symptom conditions so the heterogeneity arises from difference in strength rather than direction of association.

Irrespective of the relative risk, the prevalence of chronic fatigue and multiple chemical sensitivity amongst Gulf War veterans was relatively low (maximum estimate approximately 7\%). The prevalence of CDC-defined chronic multisymptom illness was much higher amongst Gulf veterans, but was also reported in over $30 \%$ of 
veterans who had not been deployed to the Gulf arena.

\section{Limitations of primary studies}

\section{Sample size}

The number of Gulf War veterans sampled ranged from 24 (Bell et al. 1998) to over 23000 (Simmons et al. 2004). This variation in sample size can be seen in the differential weighting of studies in the meta-analysis. Although a small sample size might be a limitation of an individual study, the possibility of a Type II error occurring in this review is minimized by the pooling of data from all appropriate studies to increase statistical power.

\section{Sample selection and response bias}

In a cross-sectional survey it is important to derive a random sample of all those subjects who are potentially eligible in order to generate a representative sample of the larger population of interest. Those studies which selected a random sample of veterans from either American, British, Canadian or Danish military personnel databases are likely to have fulfilled this criterion. However, those studies which sampled from individual military units are more prone to selection bias (Sutker et al. 1993; Bell et al. 1998; Fukuda et al. 1998; Proctor et al. 1998, 2001; Gray et al. 1999).

Furthermore, once the sample has been selected it is important to maintain its ability to represent the larger population by achieving a high response rate. In general, most of the studies achieved a satisfactory response rate of $\geqslant 70 \%$ amongst veterans of the Gulf War. However the response rate amongst non-Gulf veterans tended to be systematically lower in most studies for which data were available. Unwin et al. (1999) intensively followed up a random selection of non-responders and found that those with more symptoms responded earlier, although mean SF-36 ratings of health perception and ratings of physical function did not differ significantly by response time. There was no significant interaction between deployment, late response and health outcome since Gulf War late responders did not differ from Bosnia or era late responders. So the prevalence estimate of symptoms might be a biased overestimate, but relative measures of effect, as reported here, should be less prone to bias.

\section{Measurement of health outcomes}

All of the studies relied on the veterans' selfreport of symptoms without any alternative method of ascertainment. This is prone both to random measurement error which would tend to nullify any association between Gulf deployment and symptom reporting, and more importantly to measurement bias. All the symptoms and, therefore, case-definitions rely upon selfreport and independent ascertainment is impossible. Gray et al. (2002) quoted a kappa coefficient of 0.6 indicating moderate reliability of self-reported physician-diagnosed medical conditions but reliability was poorer (kappa -0.01 to 0.86 ) for self-reported symptoms in 139 subjects. It is noteworthy that only Sutker et al. (1993) measured the prevalence of fatigue symptoms soon after the veterans' return from the Gulf whereas the remainder of studies measured symptoms after 1994, by which time media interest in the health of Gulf War veterans might have led to an increased awareness and increased reporting of symptoms.

It is worth mentioning that the diagnostic criteria for the multi-symptom conditions that are included in this review remain controversial, and indeed it has been suggested that these 'functional somatic illnesses' might be variants of one another (Wessely et al. 1999). Some might argue that the similarity of ORs for the multi-symptom conditions supports the idea that they have a common aetiology. However, the controversial nature of these syndromes should not affect our conclusions as the studies included in the review have used the same case-definition when comparing Gulf War Veterans with those not deployed to the Gulf.

\section{Confounding}

The adjustment for confounders varied between studies (see Table 1) but the later and larger studies, which also contributed more to the meta-analysis, tended to deal with this more throughly. The studies of Goss Gilroy (1998), Ishoy et al. (1999), Unwin et al. (1999) and Cherry et al. (2001) used veterans matched on age, sex and some aspect of military status. An important confounder for these health 
outcomes would be symptom reporting before deployment to the Gulf. Ishoy et al. (1999) and White et al. (2001) asked veterans about symptoms with an onset after August 1990, but the questionnaires were administered in the late 1990s so the responses are still open to recall bias. Ishoy et al. (1999) reported that the prevalence of symptoms of fatigue with onset before August 1990 was very similar amongst Gulf and non-Gulf veterans and was much lower than the prevalence of symptoms with onset after the Gulf. This would suggest that the association between Gulf deployment and symptoms of fatigue is not confounded by baseline symptom severity.

In general, adjustment for confounders in these studies tended to reduce the strength of association between Gulf deployment and multi-symptom conditions. The results for the meta-analysis are on unadjusted findings so are likely to overestimate the association. On the other hand, the idea that deployed troops were healthier than their non-deployed counterparts is also quite plausible, at least for the US army, in which case the inability to adjust for this might suggest that the reported findings are underestimates.

\section{Strengths and limitations of this review}

This review benefits from a highly sensitive search strategy based on both published material and on grey literature such as conference abstracts and preliminary reports. Inclusion and exclusion criteria were independently assessed by two reviewers and in the case of any disagreement the reference was included until the next stage of data extraction to ensure no references were excluded unnecessarily. However, as in all systematic reviews, we may have failed to identify some studies.

This review has been limited to investigating associations between Gulf deployment versus non-deployment and reporting of various symptoms. We cannot offer any insight into the possible mechanisms underlying the observed associations. It is also possible that an association might exist between a specific environmental exposure (e.g. threat of chemical warfare agents, pyridostigmine bromide, petrochemicals, non-routine immunizations) and reporting of symptoms. We chose not to examine these associations in this review due to the problems associated with the inaccuracy of such selfreported exposures.

\section{CONCLUSION}

We identified 23 references that compared the prevalence of multi-symptom conditions in both Gulf War veterans and non-Gulf veterans. The results support the hypothesis that deployment to the Gulf War is associated with greater reporting of multi-symptom conditions. Gulf deployment was most strongly associated with chronic fatigue, with Gulf War veterans being almost four times more likely than non-Gulf veterans to report such symptoms. However it seems likely that at least some of this association might be explained by response bias, measurement bias and confounding. This review cannot shed light on any biological or socio-cultural mechanisms underlying this association but adds to the increasing body of evidence that suggests veterans of military deployment are more likely to subsequently report a variety of poorly understood complaints including fatigue, pain and associated symptoms.

\section{ACKNOWLEDGEMENTS}

We thank the Information Services Department at the University of Wales College of Medicine for assistance in obtaining references for the review. This project was funded by the Ministry of Defence through the Medical Research Council.

\section{DECLARATION OF INTEREST}

None.

\section{REFERENCES}

Bell, I. R., Warg-Damiani, L., Baldwin, C. M., Walsh, M. E. \& Schwartz, G. E. (1998). Self-reported chemical sensitivity and wartime chemical exposures in Gulf War veterans with and without decreased global health ratings. Military Medicine 163, 725-732.

Black, D. W., Doebbeling, B. N., Voelker, M. D., Clarke, W. R., Woolson, R. F., Barrett, D. H. \& Schwartz, D. A. (2000). Multiple chemical sensitivity syndrome-Symptom prevalence and risk factors in a military population. Archives of Internal Medicine 160, 1169-1176.

Bradburn, M. J., Deeks, J. J. \& Altman, D. G. (1998). Sbe24: metan - an alternative meta-analysis command. Stata Technical Bulletin 44, 4-15.

Chalder, T., Berelowitz, G., Pawlikowska, T., Watts, L., Wessely, S., Wright, D. \& Wallace, E. P. (1993). Development of a fatigue scale. Journal of Psychosomatic Research 37, 147-153. 
Cherry, N., Creed, F., Silman, A., Dunn, G., Baxter, D., Smedley, J., Taylor, S. \& Macfarlane, G. J. (2001). Health and exposures of United Kingdom Gulf war veterans. Part I: the pattern and extent of ill health. Occupational and Environmental Medicine 58, 291-298.

DerSimonian, R. \& Laird, N. (1986). Meta-analysis in clinical trials. Controlled Clinical Trials 17, 177-188.

Doebbeling, B. N., Clarke, W. R., Watson, D., Torner, J. C., Woolson, R. F., Voelker, M. D., Barrett, D. H. \& Schwartz, D. A. (2000). Is there a Persian Gulf War syndrome? Evidence from a large population-based survey of veterans and nondeployed controls. American Journal of Medicine 108, 695-704.

Fukuda, K., Nisenbaum, R., Stewart, G., Thompson, W. W., Robin, L., Washko, R. M., Noah, D. L., Barrett, D. H., Randall, B., Herwaldt, B. L., Mawle, A. C. \& Reeves, W. C. (1998). Chronic multisymptom illness affecting Air Force veterans of the Gulf War. Journal of the American Medical Association 280, 981-988.

Goss Gilroy Inc. (1998). Health Study of Canadian Forces Personnel Involved in the 1991 Conflict in the Persian Gulf, vol. 1. Department of National Defence: Ontario, Canada.

Gray, G. C., Kaiser, K. S., Hawksworth, A. W., Hall, F. W. \& Barrett-Connor, E. (1999). Increased postwar symptoms and psychological morbidity among U.S. Navy Gulf War veterans. American Journal of Tropical Medicine and Hygiene 60, 758-766.

Gray, G. C., Reed, R. J., Kaiser, K. S., Smith, T. C. \& Gastanaga, V. M. (2002). Self-reported symptoms and medical conditions among 11,868 Gulf War-era veterans. The Seabee Health Study. American Journal of Epidemiology 155, 1033-1044.

Haley, R. W., Kurt, T. L. \& Hom, J. (1997). Is there a Gulf War Syndrome? Searching for syndromes by factor analysis of symptoms. Journal of the American Medical Association 277, 215-222.

Hotopf, M., David, A., Hull, L., Nikalaou, V., Unwin, C. \& Wessely, S. (2003). Gulf war illness- better, worse, or just the same? A cohort study. British Medical Journal 327, 1357-1358.

Iowa Persian Gulf Study Group (1997). Self-reported illness and health status among Gulf War veterans. A population-based study. The Iowa Persian Gulf Study Group. Journal of the American Medical Association 277, 238-245.

Ishoy, T., Suadicani, P., Guldager, B., Appleyard, M., Hein, H. O. \& Gyntelberg, F. (1999). State of health after deployment in the Persian Gulf-The Danish Gulf War Study. Danish Medicine Bulletin 46, 416-419.

Ismail, K., Everitt, B., Blatchley, N., Hull, L., Unwin, C., David, A. \& Wessely, S. (1999). Is there a Gulf War syndrome? Lancet 353 , 179-182.

Juni, P., Altman, D. G. \& Egger, M. (2001). Assessing the quality of randomised controlled trials. In Systematic Reviews in Health Care (ed. M. Egger, G. Davey Smith and D. G. Altman), pp. 87-108. BMJ Books: London.

Kang, H. K., Mahan, C. M., Lee, K. Y., Magee, C. A. \& Murphy, F. M. (2000). Illnesses among United States veterans of the Gulf War: A population-based survey of 30,000 veterans. Journal of Occupational and Environmental Medicine 42, 491-501.

Kang, H. K., Natelson, B. H., Mahan, C. M., Lee, K. Y. \& Murphy, F. M. (2003). Post-traumatic stress disorder and chronic fatigue syndrome-like illness among Gulf War veterans: a populationbased survey of 30,000 veterans. American Journal of Epidemiology 157, 141-148.
Kipen, H. M., Hallman, W., Kelly-McNeil, K. \& Fiedler, N. (1995) Measuring chemical sensitivity prevalence: a questionnaire for population studies. American Journal of Public Health 85, 574-577.

Kroenke, K. \& Price, R. (1993). Symptoms in the community: Prevalence, classification and psychiatric comorbidity. Archives of Internal Medicine 153, 2474-2480.

Lewis, G., Churchill, R. \& Hotopf, M. (1997). Systematic reviews and meta-analysis. Psychological Medicine 27, 3-7.

Proctor, S. P., Heaton, K. J., White, R. F. \& Wolfe, J. (2001). Chemical sensitivity and chronic fatigue in Gulf War veterans: a brief report. Occupational and Environmental Medicine 43, 259264.

Proctor, S. P., Heeren, T., White, R. F., Wolfe, J., Borgos, M. S., Davis, J. D., Pepper, L., Clapp, R., Sutker, P. B., Vasterling, J. J. \& Ozonoff, D. (1998). Health status of Persian Gulf War veterans: self-reported symptoms, environmental exposures and the effect of stress. International Journal of Epidemiology 27, 1000-1010.

Proctor, S. P., White, R., Heeren, T., Debes, F., Gloerfelt-Tarp, B., Appleyard, M., Ishoy, T., Guldager, B., Suadicini, P., Gyntelberg, F. \& Ozonoff, D. M. (2003). Neuropsychological functioning in Danish Gulf War Veterans. Journal of Psychopathology and Behavioural Assessment 25, 85-93.

Reid, S., Hotopf, M., Hull, L., Ismail, K., Unwin, C. \& Wessely, S. (2001). Multiple chemical sensitivity and chronic fatigue syndrome in British Gulf War veterans. American Journal of Epidemiology 153, 604-609.

Simmons, R., Maconochie, N. \& Doyle, P. (2004). Self-reported ill health in male UK Gulf War veterans: a retrospective cohort. BMC Public Health 4, 27.

Steele, L. (2000). Prevalence and patterns of Gulf War illness in Kansas veterans: association of symptoms with characteristics of person, place, and time of military service. American Journal of Epidemiology 152, 992-1002.

Stimpson, N. J., Thomas, H. V., Weightman, A. L., Dunstan, F. \& Lewis, G. (2003). Psychiatric disorder in veterans of the Persian Gulf War of 1991: systematic review. British Journal of Psychiatry 182, 391-403.

Sutker, P. B., Uddo, M., Brailey, K. \& Allain, A. N. (1993). War-zone trauma and stress-related symptoms in Operation Desert Shield/ Storm (ODS) returnees. Journal of Social Issues 49, 33-50.

Unwin, C., Blatchley, N., Coker, W., Ferry, S., Hotopf, M., Hull, L., Ismail, K., Palmer, I., David, A. \& Wessely, S. (1999). Health of UK servicemen who served in Persian Gulf War. Lancet 353, $169-178$.

Unwin, C., Hotopf, M., Hull, L., Ismail, K., David, A. \& Wessely, S. (2002). Women in the Persian Gulf: lack of gender differences in long-term health effects of service in United Kingdom Armed Forces in the 1991 Persian Gulf War. Military Medicine 167, 406-413.

Wessely, S., Nimnuan, C. \& Sharpe, M. (1999). Functional somatic syndromes: one or many? Lancet 354, 936-939.

White, R. F., Proctor, S. P., Heeren, T., Wolfe, J., Krengel, M., Vasterling, J., Lindem, K., Heaton, K. J., Sutker, P. \& Ozonoff, D. M. (2001). Neurpsychological function in Gulf War veterans: relationships to self-reported toxicant exposures. American Journal of Industrial Medicine 40, 42-54. 